\title{
Penggunaan Model AKtivitas Investigasi Autentik YANG DIMODIFIKASI UNTUK MEMAHAMI KONSEP RASIO DAN PROPORSI
}

\author{
USING MODIFIED AUTHENTIC INVESTIGATION ACTIVITY \\ to UNDERSTAND RATIO AND PROPORTION
}

\author{
Puji Lestari \\ Pendidikan Matematika, STKIP Garut \\ Garut, Jawa Barat, Indonesia \\ neng_nji@yahoo.com
}

\begin{abstract}
Abstrak
Memahami secara komprehensif mengenai materi rasio dan proporsi masih menjadi kendala bagi beberapa calon guru, padahal kedua materi tersebut merupakan dasar dari matematika tingkat lanjut. Oleh karena itu diperlukan suatu model pembelajaran yang dapat memfasilitasi para calon guru dalam menguasai materi rasio dan proporsi. Model Aktivitas Investigasi Autentik yang dimodifikasi mampu mengoptimalkan kemampuan para calon guru pada materi rasio dan proporsi. Model ini dengan sintaks pembelajaran nya mampu membantu para calon guru lebih memahami materi rasio dan proporsi secara komprehensif. Selain itu model ini juga memberikan gambaran strategi-strategi penyelesaian soal-soal rasio dan proporsi yang beragam yang dapat menambah khasanah pengetahuan para calon guru.

Kata Kunci: model Aktivitas Investigasi Autentik yang dimodifikasi, calon guru, rasio dan proporsi.

Abstract

Comprehensive understanding on ratio and proportion are still an obstacle for some pre-service teachers, even though ratio and proportion is the cornerstone of advanced mathematics. Therefore it needs a learning model that can facilitate pre-service teachers in mastering ratios and proportions. Modified Authentic Investigation Activity is able to optimize the ability of pre-service teachers on ratio and proportions. This model with its learning syntax can help pre-service teachers more understand ratios and proportions comprehensively. In addition, this model also provides insight various strategy problem-solving of ratio and proportions that can add repertoire of knowledge of pre-service teachers.
\end{abstract}

Keyword: Modified Authentic Investigation Activity, pre-service teachers, ratio and proportions.

\section{Pendahuluan}

Masih rendahnya kemampuan calon guru maupun calon guru di berbagai negara dalam menguasai konsep rasio dan proporsi menjadikan topik ini masih menjadi sorotan sebagai kajian penelitian.
Beberapa penelitian internasional mengenai guru (in-service teacher) serta calon guru (pre-service teacher) baik sekolah dasar ataupun menengah terkait penalaran proporsional ([3], [6], [7], [1], [4]) mengisyaratkan bahwa guru serta 
calon guru masih memiliki kelemahan dalam hal pemahaman seperti nilai tempat (place value), pembagian, bilangan rasional, padahal ketiganya merupakan inti dari kurikulum sekolah dasar.

Pentingnya penguasaan materi rasio dan proporsi diungkapkan oleh beberapa ahli diantaranya menurut Lobato, pemahaman rasio dan proporsi sangat penting dalam pengembangan penalaran matematis yang lebih tinggi [7]. Dalam matematika, konsep rasio merupakan dasar dari beberapa topik matematika. Menurut Lamon kemampuan berfikir proporsional merupakan indikasi yang baik untuk memungkinkan keberhasilan siswa dalam berfikir matematika tingkat lanjut [5]. Selain itu penalaran proporsional merupakan salah satu indikator terbaik bahwa seorang siswa telah mencapai pemahaman bilangan rasional.

Hasil penelitian Ben Chaim mengungkapkan bahwa strategi pembelajaran inquiry dengan model Aktivitas Investigasi Autentik telah mampu membuat para calon guru serta guru di Israel berhasil dalam menguasai materi rasio dan proporsi [2]. Model ini dikembangkan selama beberapa tahun hingga ditemukan beberapa strategi yang mampu meningkatkan kemampuan guru maupun calon guru pada materi rasio dan proporsi. Dalam tulisan ini, akan disajikan secara ringkas bagaimana prosedur serta langkah-langkah pembelajaran menggunakan model Aktivitas Investigasi Autentik. Selain itu pada pembahasan juga disertakan hasil penelitian yang dilakukan oleh penulis dengan menggunakan model Aktivitas Investigasi Autentik.

\section{KaJIAN TEORI}

Model Aktivitas Investigasi Autentik dikembangkan oleh Ben-Chaim, Ilany \& Keret pada tahun 2001. Pengembangan model ini berdasarkan beberapa penelitian yang mengungkapkan bahwa baik guru ataupun calon guru sekolah dasar serta sekolah menengah terindikasi memiliki gap terutama dalam materi matematika terkait rasio dan proporsi. Model aktivitas investigasi autentik merupakan model pembelajaran yang melibatkan beberapa aktivitas investigasi autentik yang disajikan dalam empat bagian yang mempresentasikan situasi realistik dari masalah rasio dan proporsi di dunia nyata bagi siswa, guru, dan lingkungannya dalam berbagai level tingkat kesulitan. Model ini menggabungkan beberapa bidang utama melalui pelatihan guru maupun calon guru, khususnya di bidang pengetahuan konten (content knowledge), pengetahuan konten pedagogi (pedagogical content knowledge), penalaran pedagogis (pedagogical reasoning), pelatihan (training), dan keyakinan (belief).

Aktivitas dalam model ini meliputi pemberian tugas matematika, yang membutuhkan perbandingan bilangan secara kuantitatif maupun kualitatif antara rasio dan mencari nilai yang hilang (missing value). Tugas tersebut melibatkan bilangan bulat, pecahan, desimal, dan persen. Aktivitas ini membentuk pemahaman terhadap berbagai konsep yang terkait dengan topik rasio dan proporsi dan fokus pada 3 kategori utama 
masalah penalaran proporsional: Rate dan Density, Rasio, dan Skala.

Keempat bagian/komponen dalam model ini saling berinteraksi satu dengan yang lainnya seperti yang terlihat pada gambar 1 .

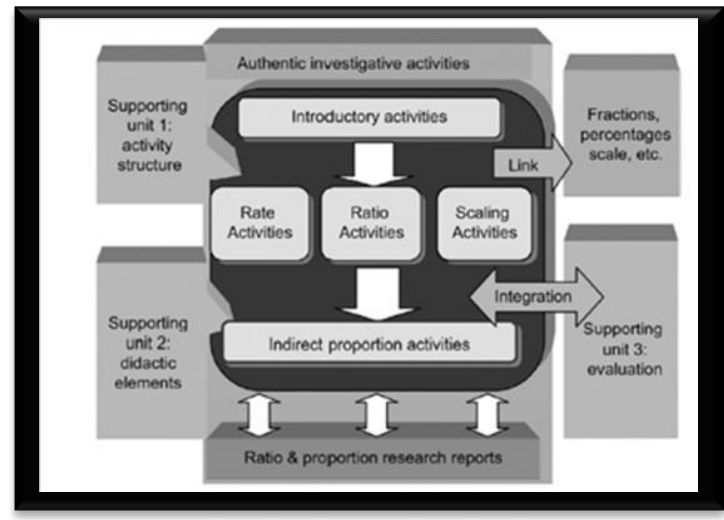

Gambar 1. Model pembelajaran menggunakan aktivitas investigasi autentik [2]

Komponen yang pertama merupakan inti dari model yang melibatkan aktivitas investigasi autentik dengan 5 tipe aktivitas yaitu aktivitas pendahuluan (introductive activities), aktivitas investigasi yang terkait dengan konsep rasio (investigative activities dealing with ratio), aktivitas investigasi yang terkait dengan konsep rate, aktivitas investigasi yang terkait dengan konsep skala, serta aktivitas investigasi yang terkait dengan proporsi tidak langsung (indirect proportion).

Komponen kedua dalam gambar meliputi struktur aktivitas. Struktur ini terkait masalah autentik investigasi yang terkait dengan konten dan konteks yang dikenal oleh calon guru serta siswa SD dan SMP. Dalam struktur aktivitas, unit pendukungnya berkaitan dengan struktur setiap aktivitas dari tiga perspektif terpisah, yaitu:
1. Perspektif Bentuk, yaitu mendeskripsikan situasi autentik yang disajikan, dan topik untuk diskusi.

2. Perspektif Konten, yaitu fokus pada penugasan matematika untuk mengembangkan konsep juga untuk memperluas dan memperdalam pemahaman.

3. Perspektif Didaktik, yaitu keseragaman proses pengajaran untuk masing-masing kegiatan diperiksa. Proses ini meliputi empat tahapan seperti bekerja dalam kelompok, diskusi, kesimpulan, pekerjaan rumah.

Komponen Ketiga yaitu Elemen didaktis yaitu berupa proses instruksi pada model ini berdasarkan pada jumlah elemen didaktik. Bagian didaktik ini memiliki 3 dimensi seperti Aktivitas Investigasi Autentik, Menilai Laporan Penelitian, dan Ringkasan.

Sedangkan komponen Keempat yaitu Evaluasi yaitu berupa kuesioner sikap, kuesioner untuk menilai pengetahuan matematika, serta petunjuk untuk membuat laporan penelitian serta porto folio.

Modifikasi model AIA ini berdasarkan asumsi bahwa karakteristik pembelajaran serta materi pembelajaran khususnya bagi mahasiswa calon guru di Indonesia berbeda dengan karakteristik para guru maupun calon guru di Israel yaitu tempat dikembangkannya model ini. Perbedaan terletak dari materi serta evaluasi pembelajaran. Berikut dijelaskan bagaimana langkah-langkah pembelajaran bagi guru/calon guru:

1. Calon guru diberikan aktivitas pendahuluan berupa pertanyaan yang 
bertujuan untuk mengetahui kemampuan awal para calon guru terhadap materi yang akan dipelajari. Selain itu aktivitas ini juga dapat membawa para calon guru keluar dari ranah pengetahuan mereka saat ini dan membawa mereka kepada konsep awal terkait dengan rasio dan proporsi. Aktivitas ini diberikan pada setiap awal pertemuan dan pertanyaan pendahuluan yang diberikan bergantung pada topik yang dipelajari.

2. Para guru/calon guru duduk secara berkelompok untuk melakukan diskusi kelompok. Proses diskusi melibatkan lembar kerja (worksheet) yang disusun berdasarkan materi rasio dan proporsi yang secara deskripsi menyajikan situasi autentik yang menyatakan fakta yang relevan untuk dipecahkan. Pertanyaan dalam lembar kerja dimulai dengan beberapa masalah yang harus dicari solusinya lalu diakhiri dengan mendefinisikan konsep-konsep yang sedang dipelajari.

Adapun materi pembelajaran rasio dan proporsi meliputi:

a. Perbandingan senilai dan berbalik nilai.

b. Rasio sebagai rate

c. Proporsi

d. Skala

3. Pemaparan hasil diskusi dipimpin oleh mentor ataupun dosen. Aktivitas ini bertujuan untuk menyamakan persepsi diantara peserta perkuliahan/pelatihan. Proses ini diakhiri dengan pengambilan kesimpulan terhadap materi yang sedang dipelajari.

4. Menganalisis hasil laporan penelitian, yaitu menganalisis jurnal ataupun artikel yang memuat hasil penelitian terkait materi yang sedang dipelajari, dengan catatan bahwa jurnal yang dikaji harus memuat strategi-strategi atau jawaban-jawaban subjeknya. Jurnal/artikel diberikan oleh mentor/dosen kepada masing-masing kelompok dan dianalisis oleh masingmasing kelompok baik dari metode, strategi yang digunakan, serta hasil penelitiannya. Tujuan dari aktivitas ini yaitu agar para guru/calon guru dapat mengetahui hasil-hasil penelitian terkait materi yang sedang dipelajari. Selain juga membuka wawasan mereka bahwa banyak para peneliti yang sudah dan sedang mengembangkan penelitian terkait materi tersebut.

5. Proses perkuliahan/pelatihan diakhiri dengan pemberian pekerjaan rumah (tugas) sebagai latihan, dan untuk memperluas pemahaman tentang materi yang sedang dipelajari. Soal-soal yang diberikan dalam tugas harus bervariasi.

6. Pemberian tugas individu di akhir pelatihan/perkuliahan terkait materi rasio dan proporsi yaitu mencari jurnal penelitian terkait materi rasio dan proporsi. Jurnal penelitian yang dipilih oleh guru/calon guru harus dianalisis dalam bahasa sendiri. Dan nantinya dikumpulkan pada akhir perkuliahan /pelatihan.

7. Wawancara, sebagai langkah akhir untuk mengetahui pandangan mahasiswa terhadap model pembelajaran Aktivitas Investigasi Autentik.

Ketujuh langkah diatas, sudah disesuaikan dengan model Aktivitas 
Investigasi Autentik yang dikemukakan oleh Ben Chaim, namun adanya beberapa modifikasi diantaranya pada materi pembelajaran serta unit evaluasi akhir yang tidak menyertakan membuat hasil penelitian serta penilaian porto folio [2]. Evaluasi hanya pada kuesioner sikap, kuesioner untuk menilai pengetahuan matematika, tugas, serta hasil analisis laporan penelitian.

\section{Pembahasan}

Efektivitas penggunaan model Aktivitas Investigasi Autentik telah dilakukan pada mahasiswa calon guru salah satu Perguruan Tinggi Swasta di kabupaten Garut. Pembelajaran dengan model ini diberikan pada mahasiswa calon guru Tingkat 1 semester II mata kuliah Kapita Selekta Pendidikan Dasar II yang memuat materi rasio dan proporsi. Pembelajaran dilakukan selama 6 kali pertemuan dengan masing-masing pertemuan memuat materi perbandingan senilai dan berbalik nilai, rate, proporsi, skala, kekongruenan segitiga dan bangun datar, serta kesebangunan segitiga dan bangun datar. Perbedaan model AIA terletak pada materi pembelajaran serta proses evaluasi. Sebelum pembelajaran, mahasiswa diberikan tes soal Kemampuan Awal Matematis (KAM) yang berisi materi prasyarat untuk memetakan kemampuan mahasiswa sebelum pembelajaran. Sedangkan instrumen penelitian kemampuan matematis materi rasio dan proporsi terdiri dari 8 soal yang reliabilitasnya. Instrumen tes untuk mengukur pengetahuan matematika para sebelumnya telah diuji validitas dan

calon guru terkait materi rasio dan proporsi dibagikan setelah para mahasiswa melakukan pembelajaran dengan model AIA.

Tabel 1.

Deskripsi Soal Tes Kemampuan Matematis Materi Rasio dan Proporsi

$\begin{array}{lll}\text { No. Deskripsi Soal Indikator } & \end{array}$

\begin{tabular}{|c|c|c|}
\hline $1 \mathrm{a}$ & $\begin{array}{l}\text { Melibatkan aktivitas rasio, } \\
\text { yaitu mencari keuntungan } \\
\text { dari dua orang partner yang } \\
\text { berinvestasi dengan } \\
\text { kuantitas yang berbeda. }\end{array}$ & 1 \\
\hline $1 b$ & $\begin{array}{l}\text { Melibatkan aktivitas rasio, } \\
\text { yaitu mencari keuntungan } \\
\text { pada tahun ke tiga dan ke } \\
\text { enam. }\end{array}$ & 1 \\
\hline $1 \mathrm{c}$ & $\begin{array}{l}\text { Melibatkan aktivitas rasio, } \\
\text { yaitu menentukan tahun } \\
\text { balik modal. }\end{array}$ & 1 \\
\hline 2 & $\begin{array}{l}\text { Melibatkan konsep rasio } \\
\text { sebagai rate dalam situasi } \\
\text { proporsi langsung, yaitu } \\
\text { menentukan efisiensi } \\
\text { penggunaan bahan bakar } \\
\text { dari dua buah mobil yang } \\
\text { berbeda. }\end{array}$ & 1 \\
\hline 3 & $\begin{array}{l}\text { Melibatkan konsep missing } \\
\text { value dalam situasi proporsi } \\
\text { tidak langsung. }\end{array}$ & 1 \\
\hline 4 & $\begin{array}{l}\text { Melibatkan rasio dalam } \\
\text { situasi proporsi langsung, } \\
\text { yaitu menentukan pilihan } \\
\text { terbaik. }\end{array}$ & 2 \\
\hline 5 & $\begin{array}{l}\text { Melibatkan rasio dalam } \\
\text { situasi proporsi langsung, } \\
\text { yaitu } \\
\text { penawaran terbaik (best } \\
\text { buy). }\end{array}$ & 2 \\
\hline 6 & $\begin{array}{l}\text { Melibatkan rasio dalam } \\
\text { situasi proporsi langsung, } \\
\text { yaitu menentukan situasi } \\
\text { terbaik. }\end{array}$ & 3 \\
\hline \multicolumn{3}{|c|}{$\begin{array}{l}\text { Indikator } \\
\text { 1: Menyelesaikan berbagai macam tipe masalah proporsional. } \\
\text { 2: Membedakan bentuk proporsional dari situasi non proporsion } \\
\text { 3: Memahami hubungan matematis yang termuat dalam situasi } \\
\text { proporsional }\end{array}$} \\
\hline
\end{tabular}


Hasil analisis terhadap aktivitas pendahuluan menunjukkan bahwa umumnya para calon guru sudah memiliki pengetahuan awal yang baik terhadap materi yang akan dipelajari. Hasil Lembar Kerja pada proses diskusi juga sudah menunjukkan hasil yang cukup baik. Kesulitan ditemukan pada Lembar Kerja dengan materi rasio sebagai rate. Hasil ini diperkuat dengan hasil tes pengetahuan matematika mahasiswa yang menunjukkan bahwa konsep rasio sebagai rate masih dianggap sulit terutama dalam memaknai konsep satuan yang berbeda.

Hasil analisis terhadap jurnal/artikel yang dianalisis oleh mahasiswa per kelompok juga cukup menggembirakan, masing-masing kelompok umumnya sudah dapat menganalisis isi jurnal/artikel dengan cukup baik, walaupun pada awal pertemuan analisisnya masih terlalu sederhana.

Berbeda dengan analisis jurnal per kelompok, jurnal individu yang diberikan pada calon guru sebagai tugas di akhir perkuliahan menunjukkan perbedaan secara signifikan. Jurnal yang didapat para calon guru sudah cukup baik, seluruhnya merupakan jurnal terkait materi rasio. Hanya saja tingkat kedalaman analisisnya justru lebih baik pada mahasiswa calon guru dengan tingkat KAM rendah. Mereka menganalisis secara komprehensif baik dari metode, strategi jawaban siswa serta hasil yang diperoleh. Sedangkan mahasiswa calon guru dari kelompok atas, hanya menganalisis secara keseluruhan. Siswa dari kelompok atas cenderung hanya memaparkan inti dari jurnal yang dianalisa, sedangkan mahasiswa kelompok tengah dan bawah cenderung menganalisis secara lengkap.

Selanjutnya juga di analisis hasil akhir dari tes pengetahuan kemampuan matematika materi rasio dan proporsi yang disajikan dalam tabel 1 . Tes ini terdiri dari 3 indikator dan masing-masing indikator diinterpretasikan kedalam 3 kategori yaitu kategori baik, sedang dan rendah. Pembagian kategori berdasarkan kepada hasil analisis jawaban mahasiswa. Selain 3 kategori tersebut, ada 1 kategori tambahan yaitu kategori sangat rendah yang menginterpretasikan hasil jawaban yang salah akibat tidak memahami maksud soal atau tidak ada jawaban. Namun kategori ini tidak dicantumkan dalam penelitian ini. Untuk lebih jelasnya, dalam tabel 2 diperlihatkan hasil perolehan tes kemampuan matematis mahasiswa:

Tabel 2.

Hasil Tes Kemampuan Matematis Mahasiswa

\begin{tabular}{|c|c|c|c|c|c|}
\hline \multirow[t]{2}{*}{ No } & \multirow{2}{*}{$\begin{array}{l}\text { Indik } \\
\text { ator }\end{array}$} & \multicolumn{3}{|c|}{ Kategori (\%) } & \multirow{2}{*}{$\begin{array}{l}\text { Rata } \\
\text {-rata }\end{array}$} \\
\hline & & Baik & Sedang & Rendah & \\
\hline $1 \mathrm{a}$ & 1 & 3 & 63 & 3 & 2.31 \\
\hline $1 b$ & 1 & 6 & 16 & 19 & 1.50 \\
\hline $1 \mathrm{c}$ & 1 & 0 & 0 & 13 & 0.81 \\
\hline 2 & 1 & 41 & 9 & 50 & 2.91 \\
\hline 3 & 1 & 59 & 3 & 31 & 3.13 \\
\hline 4 & 2 & 47 & 16 & 31 & 3.00 \\
\hline 5 & 2 & 94 & 0 & 6 & 3.88 \\
\hline 6 & 3 & 59 & 3 & 34 & 3.19 \\
\hline
\end{tabular}

Berdasarkan data pada tabel 2, pencapaian yang signifikan pada soal nomor 5, diikuti soal nomor 3 dan 6 serta nomor 4 dan 2. Berdasarkan indikator, soal-soal dengan indikator kedua yang unggul yaitu soal-soal yang membedakan bentuk proporsional dari situasi non proporsional. sedangkan indikator yang pencapaiannya belum maksimal adalah 
soal-soal yang termasuk kepada menyelesaikan berbagai macam tipe masalah proporsional.

Hasil penelitian menunjukkan adanya perubahan yang signifikan dari mahasiswa calon guru setelah mendapatkan model pembelajaran Aktivitas Investigasi Autentik.

Selanjutnya hasil pencapaian mahasiswa juga dianalisis secara kelompok. Pembagian kelompok berdasarkan hasil tes KAM. Tabel 3 berikut ini memperlihatkan hasil pencapaian uji kemampuan matematis mahasiswa untuk masing-masing kelompok:

Tabel 3.

Pencapaian Kemampuan Matematis Mahasiswa Berdasarkan KAM

\begin{tabular}{|c|c|c|c|c|c|c|c|c|c|}
\hline \multicolumn{10}{|c|}{ Kelompok } \\
\hline \multirow{2}{*}{$\begin{array}{l}\text { No. } \\
\text { Soal } \\
\end{array}$} & \multicolumn{3}{|c|}{$\operatorname{Atas}(\%)$} & \multicolumn{3}{|c|}{ Tengah (\%) } & \multicolumn{3}{|c|}{ Bawah (\%) } \\
\hline & B & $\mathrm{S}$ & $\mathrm{R}$ & $\mathrm{B}$ & $\mathrm{S}$ & $\mathrm{R}$ & $\mathrm{B}$ & $\mathrm{S}$ & $\mathrm{R}$ \\
\hline $1 a$ & 14 & 57 & 0 & 0 & 50 & 0 & 0 & 68 & 5 \\
\hline $1 b$ & 14 & 0 & 29 & 0 & 17 & 0 & 5 & 21 & 21 \\
\hline $1 c$ & 0 & 0 & 29 & 0 & 0 & 0 & 0 & 0 & 11 \\
\hline 2 & 71 & 0 & 29 & 67 & 17 & 17 & 21 & 11 & 68 \\
\hline 3 & 57 & 14 & 29 & 83 & 0 & 17 & 53 & 0 & 37 \\
\hline 4 & 71 & 14 & 0 & 33 & 33 & 33 & 42 & 11 & 42 \\
\hline 5 & 86 & 0 & 14 & 100 & 0 & 0 & 95 & 0 & 5 \\
\hline 6 & 71 & 0 & 29 & 67 & 0 & 33 & 53 & 5 & 37 \\
\hline
\end{tabular}

Hasil uji perbedaan pencapaian per kelompok kemampuan matematis mahasiswa calon guru diujikan dengan menggunakan uji Kruskal Wallis SPSS 20 dan hasilnya menunjukkan signifikansi 0.173>0.05 sehingga disimpulkan bahwa tidak ada perbedaan pencapaian baik untuk mahasiswa kelompok atas, kelompok tengah, dan kelompok bawah. Ini berarti bahwa model pembelajaran Aktivitas Investigasi Autentik mampu meningkatkan kemampuan matematis mahasiswa calon guru baik dari kelompok atas, tengah dan bawah.

Walaupun hasil akhir untuk menilai pengetahuan matematika mahasiswa calon guru dirasa belum menunjukkan hasil yang optimal, namun proses wawancara serta kuesioner sikap telah menunjukkan hasil yang cukup optimal. Pembelajaran dengan model Aktivitas Investigasi Autentik cukup menarik perhatian mahasiswa, diantaranya ketika proses pembelajaran berkelompok dengan kemampuan mahasiswa yang heterogen di tiap kelompoknya, serta menganalisa jurnal yang menurut mahasiswa itu adalah kali pertama mereka mengetahui apa itu jurnal. Kesan yang ditimbulkan para calon guru ketika menganalisis jurnal adalah menambah pengetahuan mereka. Alasannya karena mahasiswa menjadi tahu akan adanya hasil-hasil penelitian yang telah dipublikasikan diluar sana. Mereka juga berpendapat bahwa model-model pembelajaran yang digunakan untuk meningkatkan kemampuan perbandingan serta strategi-strategi penyelesaian soalsoal rasio dan proporsi dari para subjek penelitian dalam jurnal mampu menambah pengetahuan mahasiswa. Sebagai calon guru mahasiswa kini dapat memprediksi jawaban-jawaban siswa ketika mengajukan soal-soal terkait perbandingan.

Proses evaluasi yang cukup beragam pada model Aktivitas Investigasi Autentik ini menjadikan tes bukanlah satu-satunya alat ukur. Hasil kuesioner sikap menunjukkan bahwa mahasiswa umumnya setuju bahwa mereka sudah memiliki rasa percaya diri yang tinggi dalam penguasaan 
materi rasio dan proporsi, namun masih banyak para calon guru yang masih belum percaya diri untuk mengajarkan materi rasio dan proporsi. Hal ini bukan karena mahasiswa tidak menguasai konten rasio dan proporsi, tetapi lebih kepada mahasiswa masih belum memiliki pengalaman ataupun penguasaan yang baik dalam aspek pedagogis. Bisa dimaklumi mengingat mereka masih mahasiswa di tingkat 1 sehingga masih memerlukan lebih banyak pendalaman mata kuliah yang mendukung kemampuan pedagogis.

\section{Penutup}

Model Aktivitas Investigasi Autentik yang dimodifikasi mampu melatih pengetahuan konten matematis para calon guru terkait materi rasio dan proporsi. Selain menambah penguasaan konten rasio dan proporsi para calon guru karena disajikan secara runtut sesuai dengan tahapan aktivitas modelnya, model ini juga berhasil menambah pengetahuan mahasiswa mengenai strategi-strategi penyelesaian soal-soal rasio dan proporsi, karena model Aktivitas Investigasi Autentik menyertakan hasil-hasil penelitian baik dalam jurnal ataupun artikel yang menampilkan beragam model pembelajaran yang digunakan untuk dapat menguasai konsep perbandingan maupun strategi-strategi yang digunakan oleh subjek (siswa) dalam menjawab soal-soal rasio dan proporsi. Selain itu, model ini juga berhasil membuka pengetahuan mahasiswa bahwa soal-soal yang aplikatif dalam dunia nyata mampu lebih efektif untuk membuat mahasiswa lebih memahami serta memaknai konsep rasio dan proporsi.

\section{DAFTAR PUStaka}

[1] D. Ben-Chaim, Y. Kerret, \& S-B. Ilany, "Designing and implementing authentic investigative proportional reasoning tasks: the impact on preservice mathematics teachers' content and pedagogical knowledge and attitudes", J Math Teacher Educ (2007)

$$
\text { 10:333-340 }
$$

DOI 10.1007/s10857-007-9052-x:

Springer Science+Business Media B. V. 2007.

[2] D. Ben-Chaim, Y. Kerret, \& S-B. Ilany, Ratio and Proportion. Research and Teaching in Mathematics Teachers' Education (Pre- and In-Service Mathematics Teachers of Elementary and Middle School Classes), Sense Publisher: Rotterdam, 2012.

[3] R. Ekawati, Fou-Lai Lin, Kai-Lin Yang, (2014, April). "Developing An Instrument For Measuring Teachers' Mathematics Content Knowledge On Ratio and Proportion: A Case of Indonesian Primary Teachers", International Journal of Science and Mathematics Education 2014.

[4] F. A. Hillen, Examining Pre-service Secondary Mathematics Teachers' Ability to Reason Proportionally Prior To and Upon Completion of A Practice-Based Mathematics Methods Course Focused on Proportional Reasoning. 
Dissertation: University of Pittsburgh, 2005.

[5] S. Lamon, Teaching fractions and ratios for understanding: Essential content knowledge and instructional strategies for teachers, Mahwah, NJ: Lawrence Erlbaum, 1999.

[6] S. Livy \& S. Herbert, "Pre-Sevice Teachers' Responses for Ratio and Proportion Items", In V. Steinle, L. Ball \& C. Bardini (Eds.). Mathematics education: Yesterday, today and tomorrow, Proceeding 36th annual conference of the Mathematics Education Research Group of Australia, M elbourne: VIC: MERGA, 2013.

[7] J. Lobato, H. C. Orrill, B. Druken, \& E. Jacobson, "Middle School Teachers' Knowledge of Proportional Reasoning for Teaching", Paper presented at Annual Meeting of the American Educational Research Association: New Orleans, 2011.

[8] B. O. Steinthorsdottir \& B. Sriraman, Icelandic 5th grade girls developmental trajectories in proportional reasoning, 2009.

Riwayat Hidup PenUlis

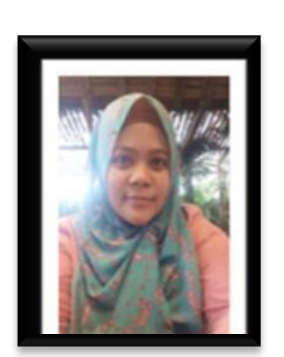

Puji Lestari, S.Si. M.Pd. Lahir di Bandung, 8 Januari 1984. Staf pengajar di STKIP Garut. Studi S1 Matematika Universitas Islam Band bbnn ung, lulus tahun 2005; S2 Pendidikan Matematika Universitas Pendidikan Indonesia, Bandung, lulus tahun 2009; dan saat ini sedang melanjutkan S3 Pendidikan Matematika di Universitas Pendidikan Indonesia,
Bandung. Penulis cukup aktif dalam mengikuti kegiatan seminar pendidikan matematika baik secara nasional maupun internasional serta sudah melakukan beberapa publikasi secara nasional baik dalam bentuk prosiding maupun jurnal. Penulis juga pernah mempresentasikan sebuah poster penelitian dalam Konferensi Seminar Pendidikan Matematika Internasional (EARCOME 6) di Phuket, Thailand. 

e-mosharafa.org

This page is intentionally left blank 